\title{
A Study on Strategy of Introducing Business English into Public English Teaching in Higher Vocational Colleges
}

\author{
Xiang Yang \\ Baoshan College of Traditional Chinese Medicine, Baoshan Yunnan, 678000, China
}

Key words: Higher vocational colleges, Public English, Teaching, Business English, Strategy.

\begin{abstract}
The aims of reform of English teaching of higher vocational colleges in China show that business English training has become the primary task. As far as students of higher vocational colleges are concerned, the aim of English learning has changed to be related to school work, occupation and employment. Hence, higher vocational colleges should take the explicit demands of students into consideration when offering public English course, and it is necessary to introduce business English. In view of this, higher vocational colleges, as employment-oriented colleges, should consider how to effectively introduce business English into public English teaching to train students to adapt to the needs of job market. This paper aims to, starting from the necessity of introducing business English into public English teaching in higher vocational colleges, analyze the current situation of public English teaching of higher educational colleges, and discuss strategies of introducing business English into public English teaching in higher vocational colleges.
\end{abstract}

\section{Introduction}

Anthropological linguistician held that language develops with the development of human society, and plays an important role in social activities. According to this theory, a large number of English talents are needed to shoulder the first-line work, which is exact the aim of higher vocational colleges to offer public English courses. Hence, the "business-orientation" of public English teaching has become a trend. To this end, higher vocational colleges should adjust their teaching strategies to facilitate students' fully developing their English competence in work.

\section{Advantages of Introducing Business English into Public English Teaching in Higher Vocational Colleges}

Higher vocational colleges offer public English courses to help students to adapt to jobs, and meet the English competence requirement in job market. This shows that the relevance of public English to business English is obvious. Higher vocational colleges have carried out reform of public English courses several years. From the reform orientation, the popularization, fundamentality and practicability of public English courses are reserved, and introducing business English is a prominent measures[1]. Business English teaching is carried out to help students to adapt to job market and apply English in specific field for communication. Thus, the application of business English is superior to that of general English. Effectively combining public English with business English is a difficulty of English teaching for higher vocational colleges.

\section{Promote social development.}

Adding business English content to public English complies with the aim of higher vocational colleges of imparting knowledge and educating people. Through several decades of development since the reform and opening-up policy, China has entered a new development period, and more and more talents are demanded in various industries. Under such a circumstance, top priority is given to 
cultivation of talents with comprehensive vocational ability. The external communication ability supported by English communication skills is a favorable factor for industry development.

\section{Push forward education reform.}

The documents on education reform promulgated by the Ministry of Education provide special guiding suggestions on improving vocational education and teaching quality for higher vocational colleges. It was explicitly pointed out that higher vocational colleges should work hard to train high-quality skilled talents for the socialist modernization by means of combination of production and study so as to render services and facilitate students in employment market[2]. Thus, stress should be laid on students' comprehensive occupational ability in vocational education reform. To improve students' ability, the primary task of higher vocational education is to adjust the courses, change the basic requirements of course teaching, and focus on the applicability and practcalness of English teaching.

\section{Facilitate students' development.}

The 21st century is a period when global economy rapidly develops. Inter-disciplinary talents with certain language application ability are in bad need. Based on social needs, higher vocational education should be carried out to create favorable conditions for students, and improve students' language ability to certain level, so as to help students to develop better in work.

\section{Current Situation of Public English Teaching of Higher Vocational Colleges}

The educational objectives of higher vocational colleges are to train high-level application-oriented skilled talents meeting the needs of first-line work, including production, construction, management, service, etc. The requirements on higher vocational colleges raised by the Ministry of Education provide the basic requirements for English teaching of higher vocational colleges[3]. Higher vocational colleges, on this basis, strive to improve students' English language ability, and impart more practical public English contents to meet market requirements. Actually, it is very difficulty for higher vocational colleges to realize this objectives. Presently, public English teaching in higher vocational colleges is not much different from that in senior high schools in respect of content, teaching difficulty, teaching methods and teaching means. Thus, most graduates from higher vocational colleges can hardly meet their work needs in respect of English application ability. Through a close consideration, we can know that there are fundamental problems. For example, the teaching materials of public English teaching are too universal; the public English teaching environment is different from the work environment; the evaluation of higher vocational English ability doesn't comply with job performance evaluation; the methods and means of English teaching are backward, etc. Teachers are still persisting in traditional teaching mode, which is the primary reason why the bottleneck of public English teaching of higher vocational colleges cannot be broken through.

\section{Strategy of Introducing Business English into Public English Teaching in Higher Vocational Colleges}

\section{To integrate work environment into public English teaching environment}

Higher vocational education has been being carried out according to the idea of "combination of learning with working". Under the impact of this idea, public English teaching should be carried out to provide a practice platform for students to improve students' ability of language application. "Order-oriented" talent cultivation mode is an effective way to provide a practice platform to students[4]. Specifically, higher vocational colleges can found an English teaching practice base, and cooperate with enterprises and public institutions engaged in foreign affairs or closely related to the specialty to create environment and conditions for training students' vocational English ability. 
Concerning on-campus teaching, teachers an improve English teaching methods and means, organizing teaching activities with various teaching methods based on the new idea of business English. Concerning the application of teaching means, teachers can make use of multi-media teaching attachments to create a multi-dimensional English learning environment by presenting business English audio-visual materials supporting the teaching materials. Concerning the application of teaching methods, teachers can employ the task-driving language teaching method. Task-driving language teaching method refers to helping students to improve their language application ability via fulfilling specific tasks. For example, teachers can set a scenario that a company participates in the China Import and Export Fair, inform students of the main businesses, main products, production technology and industry impacts of the company, and assign tasks to students. Task I: receive regular customers; task II: develop new customers. Students will encounter problems about translating/interpreting related information of the company, getting access to information of other companies via the internet, and communicating with customers, and then teachers can help students to solve problems. In this way, students can get improved in respect of business English application ability.

In addition, the setting of teaching objectives also should be emphasized in higher vocational public English teaching, to meet classroom teaching objectives and enterprise needs. In a word, a specific English application level should be designated for public English teaching activities so as to make teaching plans and design teaching contents purposefully.

\section{To integrate work content into public English teaching materials}

The compilation and correction of today's higher vocational public English teaching materials still follow the traditional teaching objectives. Thus, the teaching materials mainly contain communicative sentences for daily life, but seldom include business English contents. In view of this, more business English contents supporting students' specialties should be added to achieve the aim of "combination of learning with working". In this way, students can learn practical English knowledge and improve their business English application ability.

Higher vocational colleges should lay their stress on two aspects: selecting different English teaching materials for different specialties; selecting English teaching materials according to the objectives of training English application ability. All specialties offered by higher vocational colleges are specific to certain fields or trades. Thus, colleges should consider this when selecting public English teaching materials to perform individualized quality education". In this way, the training of students' English application ability can be carryout out based on the specialty demands, to help students to lay a solid foundation for specialized knowledge application in work in future. Teachers should design teaching contents closely related to specialties based on work needs, to guarantee the quality of higher vocational public English teaching and comply with students' requirements for self-development. Higher vocational education is carried out to train talents to address the work needs in the society, thus higher vocational public English teaching should be carried out to train students' ability of adapting to work. To improve students' language application ability and communication and interpersonal skills is urgent to be realized through public English teaching. To this end, the current learning status of college students must be improved and optimized. Teachers of public English course should attach more importance to enhancing students' language application ability, and select teaching materials based on students' development orientation to meet their demands[5]. Nevertheless, the base position of listening, speaking, reading, writing and translating should still be held, and students' English application ability training should be carried out on this basis, to realize the ultimate goal of public English teaching.

To integrate the job performance evaluation method into the evaluation of higher vocational English ability.

The creation of work environment and addition of work contents mean change to public English teaching of higher vocational colleges. To fully realize the reform goal, the existing higher vocational public English ability evaluation mode also should be changed. The examination-based evaluation 
mode has shown its defects. Specifically, the individual differences of students are not considered in examination, and examination is not helpful for students to bring their subjective initiative into play. Higher vocational colleges have been adhering to the principle of "combination of working with studying". Thus, the original teaching contents and methods can be retained, and new contents and methods can be developed on this basis. In particular, the training of students' business English application ability should be carried out based on the career development direction of students in future, and scientific comprehensive specific evaluation method should be selected for this purpose. The application of diversified evaluation methods in higher vocational public English teaching activities can strengthen students' learning initiative, helping students to improve their English application ability; guarantee the quality of English teaching, consolidating students' language expression ability and practical application ability. Thus, colleges can cooperate with enterprises, to determine evaluation plan together, and enrich the evaluation methods of English ability. Enterprises' evaluating students' English application ability can enhance students' business English experience; and is practical and realistic. Besides, in higher vocational English teaching activities, teachers should consider students' demands for basic English ability and career ability, develop specific qualification examinations, to perform evaluation over students' English ability by means of combining professional ability evaluation with English ability evaluation. Besides qualification examinations, English reading and debates also are effective to enhance students' practical English practice ability.

\section{Public English teachers act as career tutors}

As far as public English teachers are concerned, to teach students to flexibly apply English knowledge they learnt in work, they should improve themselves. In classroom activities, teachers are guides to students, and teachers' professional quality level determines the quality of higher vocational public English teaching. To achieve teaching objectives, teachers, besides guaranteeing their teaching ability, also should teach students based on students' specialty study, to guide students to apply business English properly. Presently, some higher vocational public English teachers have no clear understanding about the particularity of higher education and the practicability and occupation-orientation of teaching objectives, so that they cannot teach students to develop a definite direction of learning. Public English teachers should act as career tutors, applying the latest career information in relation to English teaching in classroom teaching based on the characteristics of students.

To help public English teachers to act as career tutors, higher vocational colleges should cooperate with enterprises and public institutions, sending outstanding young teachers to units for training. Teachers can get firsthand information about the latest work ideas through going to the work environment, and learn about the true demands for English knowledge and ability in work market. Besides, teachers can learn the training mode from professional career tutors, which helps them to enrich teaching methods and revitalize teaching contents.

\section{Conclusion}

To sum up, it is imperative to introduce business English into pubic English teaching of higher vocational colleges to achieve the teaching objectives of higher vocational colleges and enhance students' enthusiasm for English learning so as to improve students' comprehensive business English ability. Presently, with the constant development of economy, the demand for English application talents in various fields takes on an increasing trend. Sin view of this, higher vocational colleges make English teaching education program suitable for students and introduce business English, and are striving to improve students' comprehensive English ability by integrating work environment into public English teaching environment, integrating work content into public English teaching materials, integrating job performance evaluation into higher vocational English ability evaluation mode, and having public English teachers act as career tutors, to help students to give full play to their English ability in work. 


\section{References}

[1] Yao Xiaoting, Mao Lingling. Analysis on the Strategy of Introducing Business English into Public English Teaching of Higher Vocational Colleges, Journal of Wuxi Vocational Institute of Commerce, 2013, 01:70-72.

[2] Jian Jianfen. Research and Analysis on the Reform Idea of Introducing professional English into Public English Teaching of Higher Vocational Colleges, Communication of Vocational Education, 2013, 18:15-17.

[3] Yao Haiyan. Several Considerations on Combination of Public English Teaching Reform of Higher Vocational Colleges with Job Market, Communication of Vocational Education, 2013, 29:34-35.

[4] Guo Lili. Discussions on Job-orientation of Higher Vocational English Teaching, Vocational \& Technical Education Forum, 2014, 27:76-78+91.

[5] Ji Ying. Brief Analysis on Training of Business English Ability in Higher Vocational English Teaching, New Curriculum Research (Middle-ten-day), 2016, 03:54-55. 